
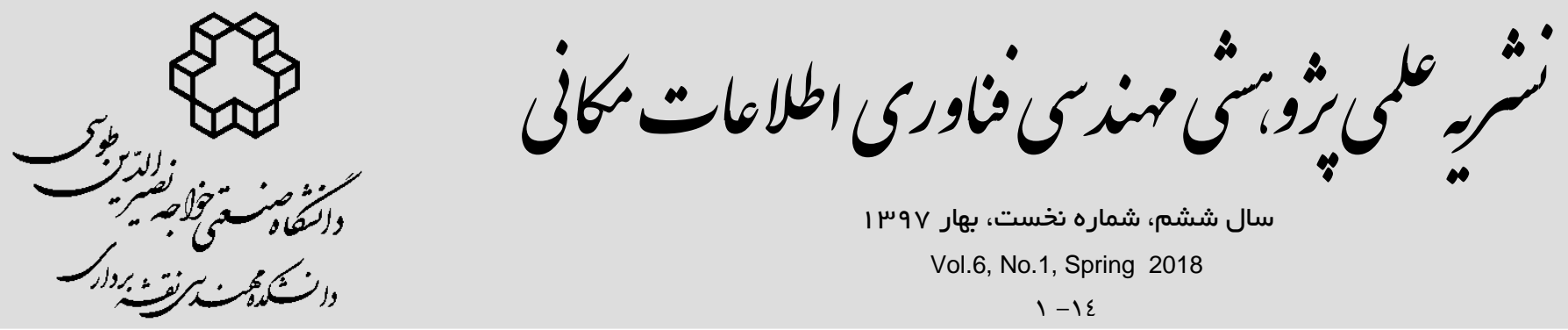

\author{
تركيب تصاويرابرطيفى هوايى و دادههاى ليدار براى توليد عوارض شهرى

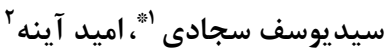 \\ 1- استاديار دانشكده نقشهبردارى دانشگاه تفرش

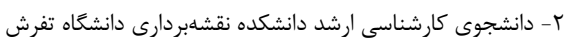

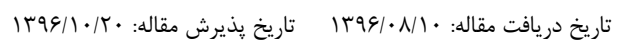

جكيده

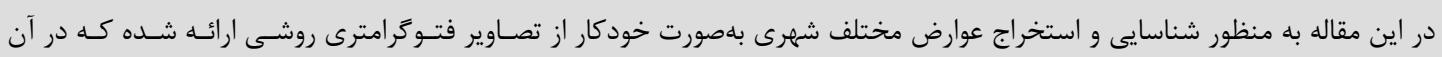

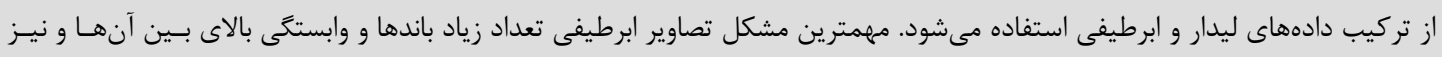

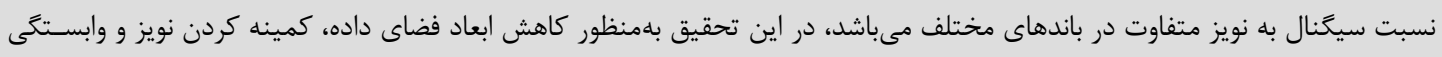

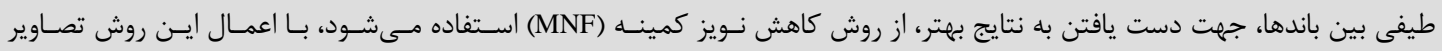

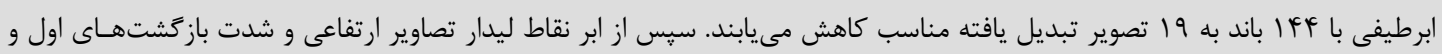

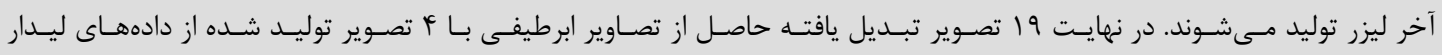

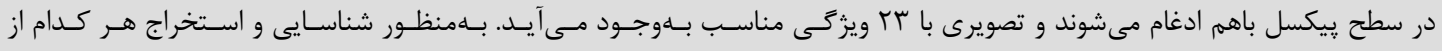

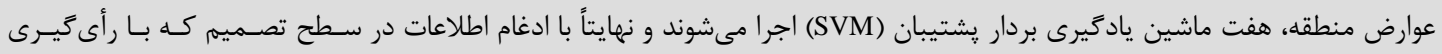

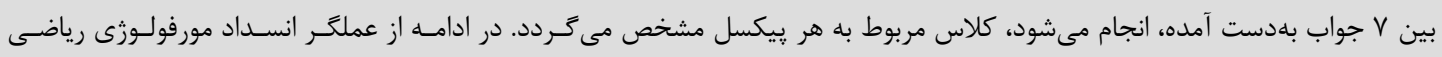

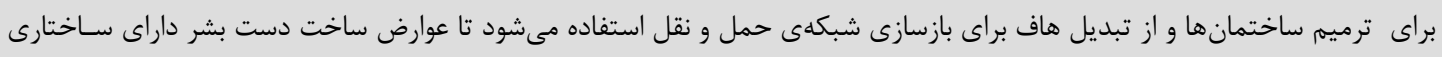

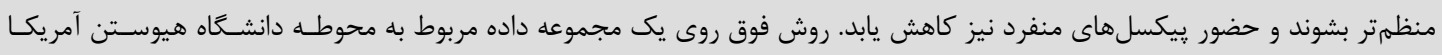

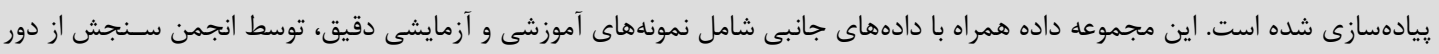

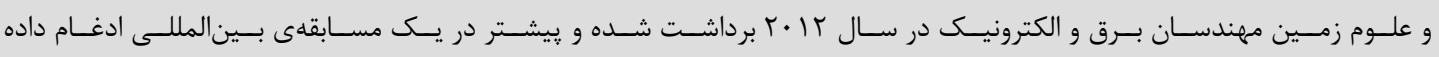
مورد استفاده قرار كرفتهاند.

كليد وازمها : تصاوير ابرطيفى، ليدار، ماشين بردار يشتيبان، مورفولوزى، ادغام.

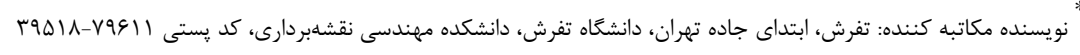




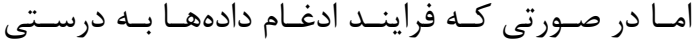
صورت بخيرد، مجموعهاى از اطلاعات در اختيار خواهند

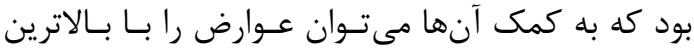

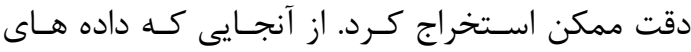

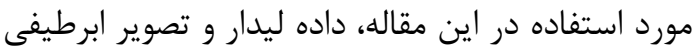

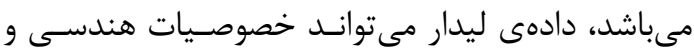

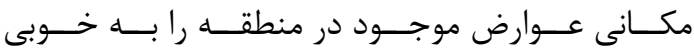
نمايش دهد، اما تصوير ابرطيفى قابليت بسيار بالايى در

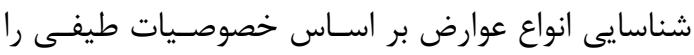

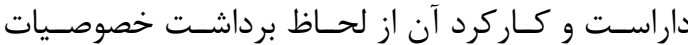
هندسى ضعيف است. كاربرد دادهى ليدار در سنجش از دور و فتوكرامترى محدود به عوارضى اسـت كـه داراى

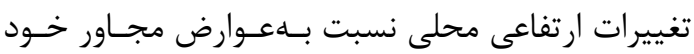

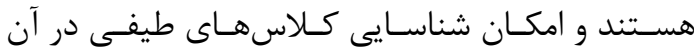

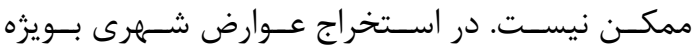
ساختمان خصوصيات هندسى و مكـانى مناسـبتــرين

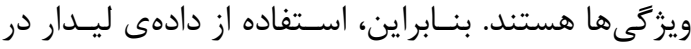

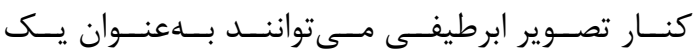
مكمل يكديخر عمل كنند. ادغام داده هـاى سـنجش از

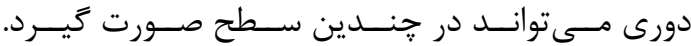
بهطور كلى سه سطح براى ادغام داده ها مطــرح اسـت: ادغام تصاوير در سطح بيكسل، ادغام تصـاوير در سـطح عارضــه و ادغــام تصـاوير در ســطح تصـميم. در ادغــام تصاوير در سـطح קيكسـل، همـهى تصـاوير بـهـ صـورت

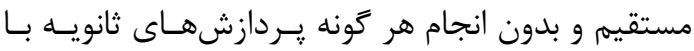
يكديخر تلفيـق مسىشـوند. در ادغــام تصـاوير در سـطح

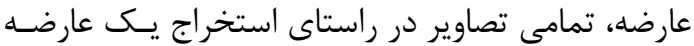

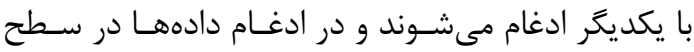

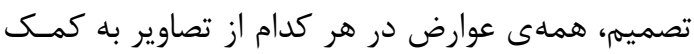

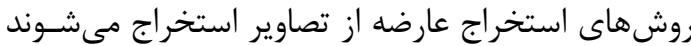

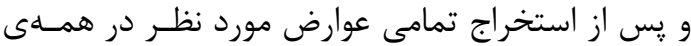

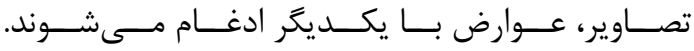
اغلب روشهاى ادغام دادهى موجود، از روش ادغام داده در سطح تصميم و عارضه استفاده مسىكنــد. در ادغـام دادهها در سطح يِيكسل، امكان حضور نويز در هر كـدام
- 1- مقدمه

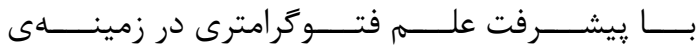

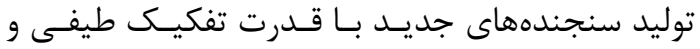

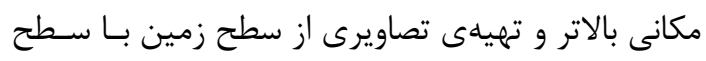

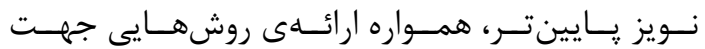

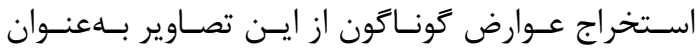
موضوعى مهمم مد نظر دانشمندان و محققين بوده است. وجود سنجندههاى مختلف و تنوع دادههاى تهيـهـ شـده

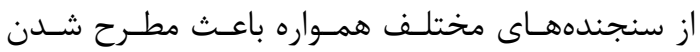

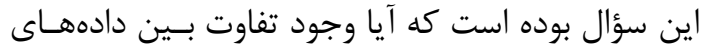

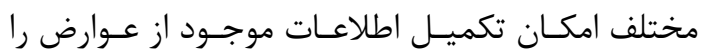
فراهم مى كند يا خير؟ پاسخخهاى فراوانى به ايـن سـؤال

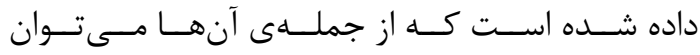

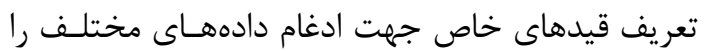

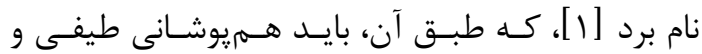

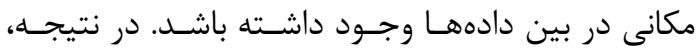

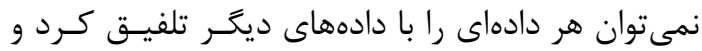

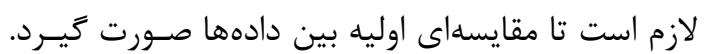

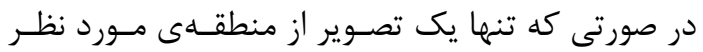

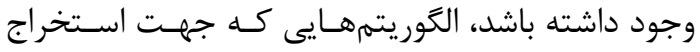
عوارض معرفى خواهند شد، محدود به باندهاى طيفى و

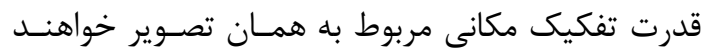

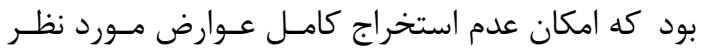
بهدليل كافى نبودن دادههاى اوليه وجود خواهد داشت، ولى در صورت استفاده از مجموعهاى از دادههاى طيفى نوادي و مكانى به طور همزمان كه داراى خصوصيات متفـاوتى

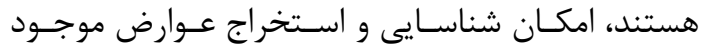

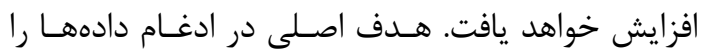

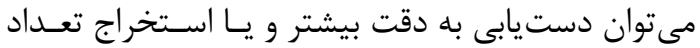

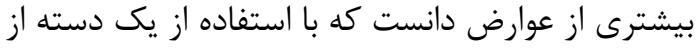
دادهها قابل استخراج نباشد. اكر با افزودن دادهى جديد،

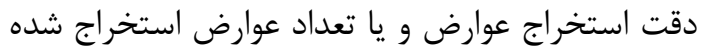

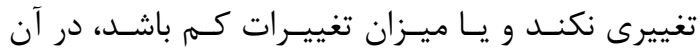

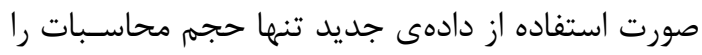
افزايش داده است و استفاده از آن بى ارزش خوات خواهد بوداديا 
ارتفاع بهترتيب از تصـاوير ابرطيفى و ليــار موجـود از

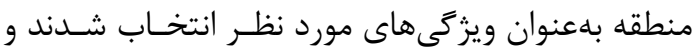

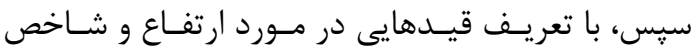

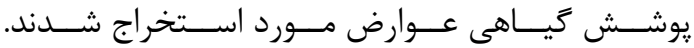
در روش نظارت شده با اسـتفاده از روش كـاهش ابعـاد

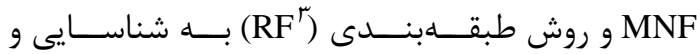

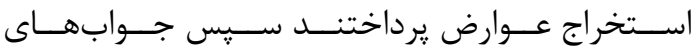

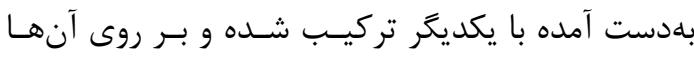

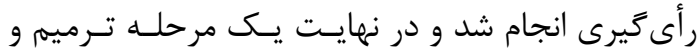

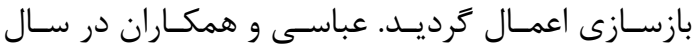

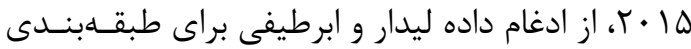

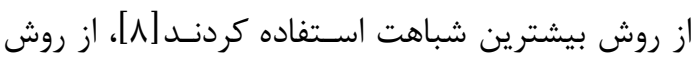

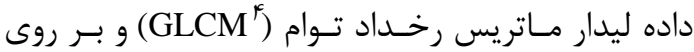

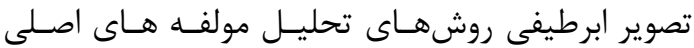
و وسر نويز كمينه (PCA (PCA $\left.^{\natural}\right)$

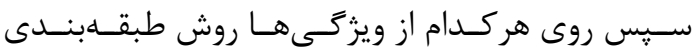
بيشترين شباهت اعمال كرديد و در نهايت جـوابهــاى بهدست آمده با الخوريتهم بيزن ادغام شدند.

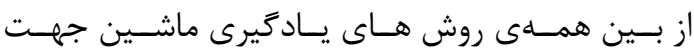
طبقهبندى عوارض، بيشتر از روش ماشينبردار رشتيبان

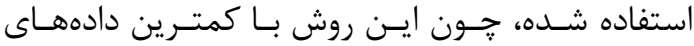

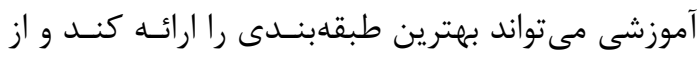

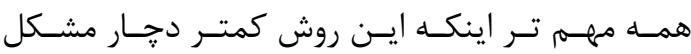
بيش برازش ل مئشود.

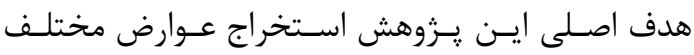

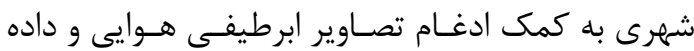

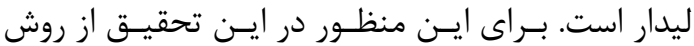

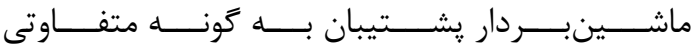
بهره كرفته شده است. بـدين ترتيـب كـهـ بـراى تعيسين

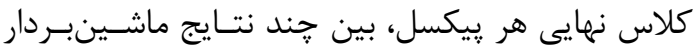

\footnotetext{
${ }^{3}$ Random Forest

${ }^{4}$ Gray Level Co-Occurrence Matrix

${ }^{5}$ Principal Component Analysis

${ }^{6}$ Minimum Noise Fraction

${ }^{7}$ Overfitting
}

از باندها و انتقال آن به ديخر باند ها و در نتيجــه امكـان توليد خطا در نتايج كـلاسبنـدى وجـود دارد. در روش

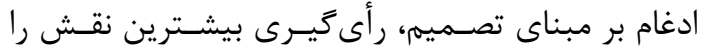
ايفا مى كند [r]. بدينمنظور مقالات زيادى به اسـتفاده

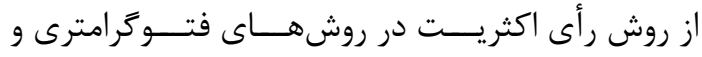

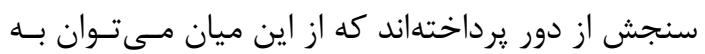

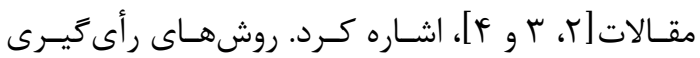

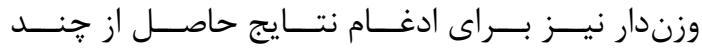

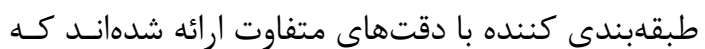
به وزندهى به نتايج بر اساس كيفيت و دقت هـر كـدام از روشهاى طبقهبندى كننده مى يردازند [ [ و و ها].

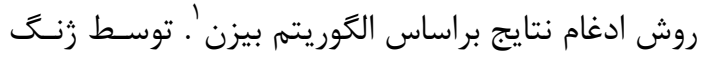

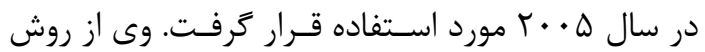

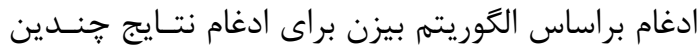

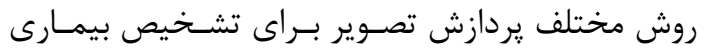

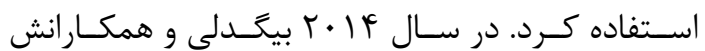
روشى براى طبقهبندى عوارض شهرى از تلفيق تصـاوير

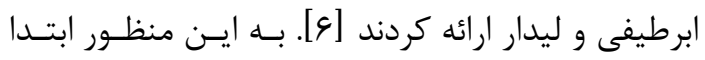

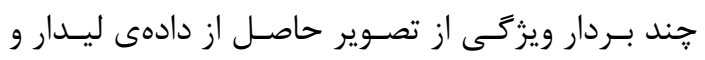

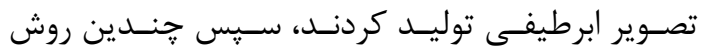

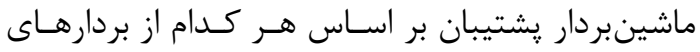

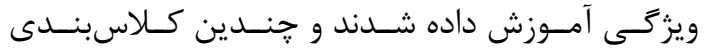
متفاوت توليد كردند و در آخر بين نتايج بهدست آمـده

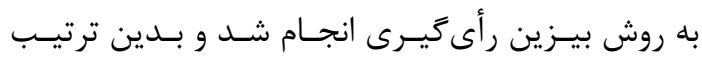
عوارض موجود از منطقه استخراج شدند. روش بركزيده ادغام داده ها توسط انجمن سنجش از دور و علوم زمين

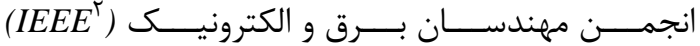

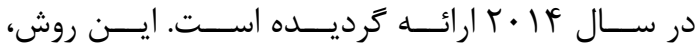
از دو روش مختلف جهت كلاسبنـدى تصـاوير موجـود

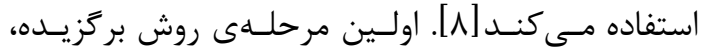

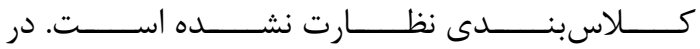
كلاسبندى نظارت نشده، ابتدا شاخص يوشش گياهى و ند

\footnotetext{
${ }^{1}$ Bayesian Theorem

${ }^{2}$ Institute of Electrical and Electronics Engineers
} 
با سيستم مختصات جغرافيايى GCS-83 اخذ شـدهانـد. لذا، نيازى به تبديل سيستم مختصات در منطبق كردن

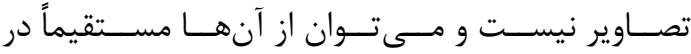

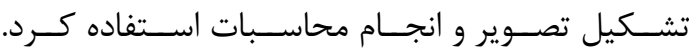
شكل (1) تركيب رنكى كاذب منطقه را نشان مىدهد.

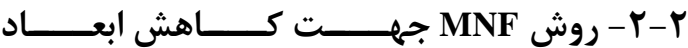
فضاى ويزَّى روش MNF كه حالت تعمـيم يافتـه روش PCA اسـت،

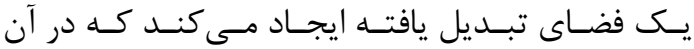

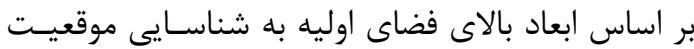

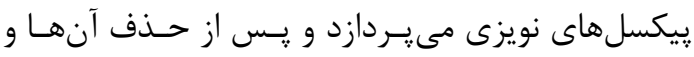

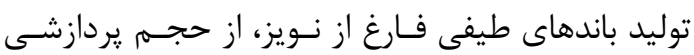

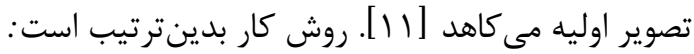
اگر تصوير ابرطيفى با d باند در اختيار داشته باشيم كـهـ

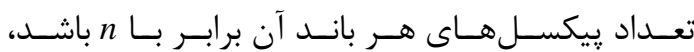

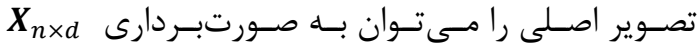
نمايش داد. رابطه (1) [1 ا]"

$$
\boldsymbol{X}=\left(X_{1}, \ldots, X_{n}\right)^{T}
$$

هر بردار طيفى موجــود بـراى هــر يـيكسـل كـهـ شـامل مقادير طيفى ثبت شده براى يك ييكسـل در بانـدهاى طيفى مختلف است را مى توان بلهـورت حاصـل جمـع

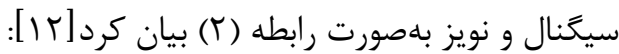
$X_{i}=S_{i}+N_{i}$

رابطه (r) با فرض عـدم وابسـتخى سـيخَنال و نـويز مسى تـوان بــه رابطه (ז) دست يافت [برص إ): $\sum_{X}^{T}=\sum_{X}^{S}+\sum_{X}^{N} . \quad$ رابطه (广) كه در آن براى تمام مقـادير i داريـه: ,

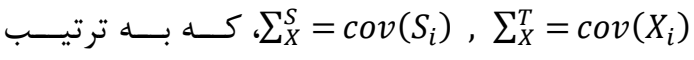
عبارتند از: ماتريسهاى كواريـانس مجمـوع، سـيخَنال و

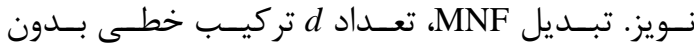

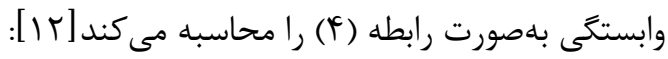
$v_{i k}=a_{k}^{T} X_{i} \quad, \quad k=1, r, \ldots, d \quad$ (أl) اين رابطه، به خوبى مى تواند مقدار نويز را كمينــه كنـد.

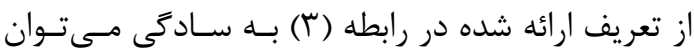

يشتيبان مختلف راى گيرى انجام مىشـود. در نهايـت از

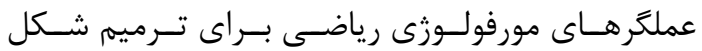

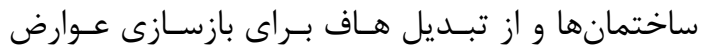

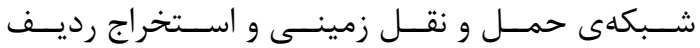

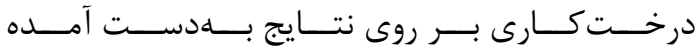
استفاده مى شود تا عوارض ساخته شـده توســ انسـان داراى ساختارى منظم تر بشوند.

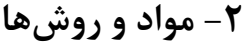

در ادامه به معرفى دادههاى مــورد اسـتفاده و روشـهاى استفاده شده يرداخته مىشود.

r-1 دادههــاى مــورد اســتفاده و منطقــه مسـورد مطالعه دادههاى مورد استفاده توسط انجمـن سـنجش از دور و

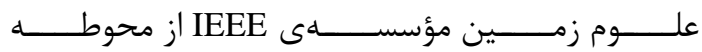

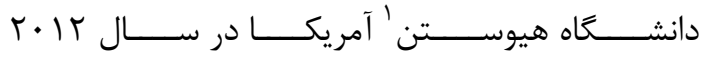
برداشت شدهاند. اين مجموعه داده شامل دو منبـع داده

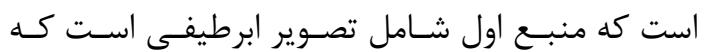
داراى FF I باند طيفى در حوزههاى مرئى و مادون قرمز نزديك و ميـانى اسـت. قـدرت تفكيـك مكـانى تصـوير

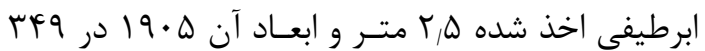

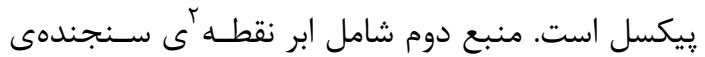
ليدار هوايى با تراكم ا نقطه در هر ه/ر متر مربع اسـت كه بهعبارتى ديخر مى توان قدرت تفكيك مكانى مربـوط

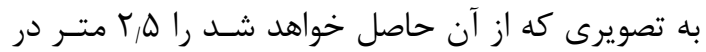
نظر گرفت. اين مجموعه داده شامل امـواج باز گثـتى از عوارض منطقه در ه سطح مختلف است كه ميزان نفوذ

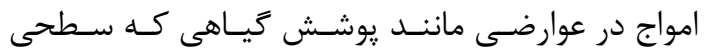

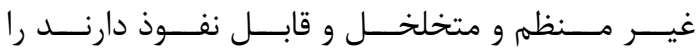
نشان مىدهـــ. تصـوير ابرطيفـى و نقــاط ليـدار نيـز در

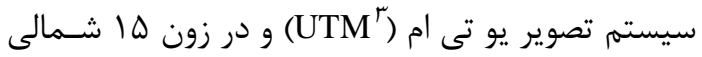

\footnotetext{
${ }^{1}$ Huston

${ }^{2}$ Point Cloud

${ }^{3}$ Universal Transvers Marcatur
} 


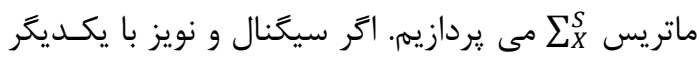

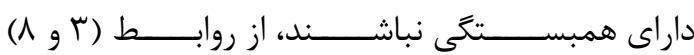
خواهيم داشت (رابطه (• ()): $A \sum_{X}^{T} A^{T}=\Lambda+I, \quad A \sum_{X}^{N} A^{T}=I \quad($ ) رابطه

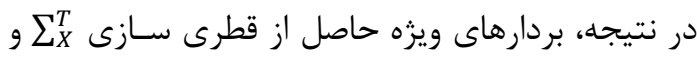

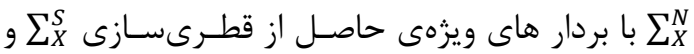

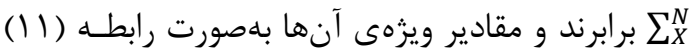

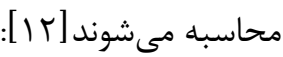
$\mu_{i}=\lambda_{i}+1, \quad i=1, r, \ldots, d \quad$ (1)

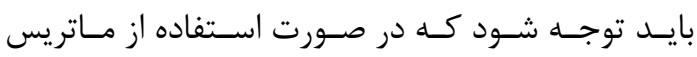

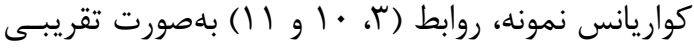
برقرار هستند. بهعنوان يكى از دلايل آن نيـز مسىــــوان

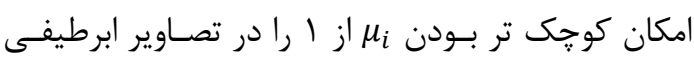

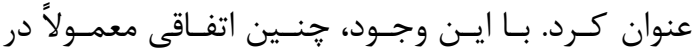
باند x هاى آخر تصوير ابرطيفى كه از نسبت سيخنال به

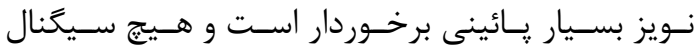

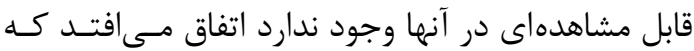

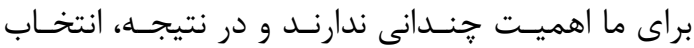

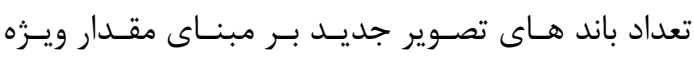
بزر كتر از r در نظر كرفته مىشود.

r-r-r- طبقدبندى كننده ماشين بردار يشتيبان

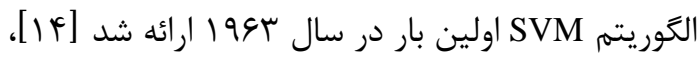

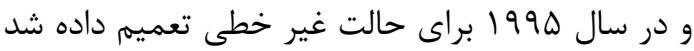

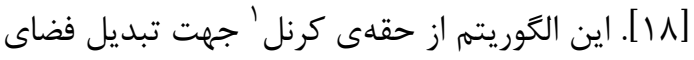

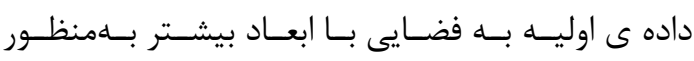
سادهازى مسئله استفاده مى كند [ه|] در روش ماشينهاى بردار קشتيبان، بردارهاى ورودى به

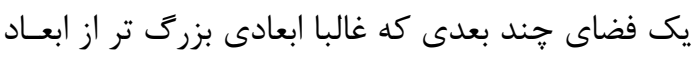

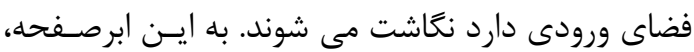
ابرصفحه با حداكثر مرز جداكننده كفته مىشود.

\footnotetext{
${ }^{1}$ Kernel Trick
}

دريافت كـهـ نسـبت سـيخَنال بـه نــويز بــراى $k$ امسين

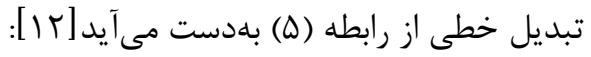
رابطه (d) $S N R_{k}=a_{k}^{T} \sum_{X}^{S} a_{k} / a_{k}^{T} \sum_{X}^{N} a_{k}, \quad k=1, r, \ldots, d$

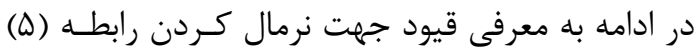
يرداخته مىشود (روابط (و و (V)). $a_{k}^{T} \sum_{X}^{N} a_{k}=1, \quad k=1, r, \ldots, d \quad$ رابطه (צ)

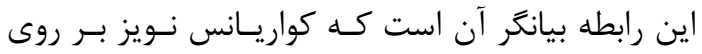

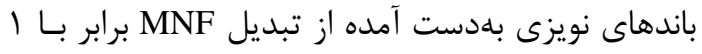

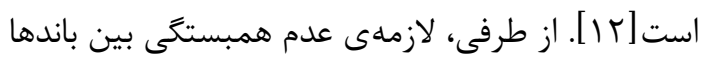

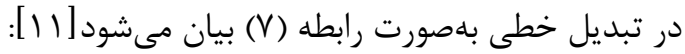

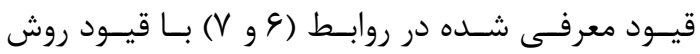

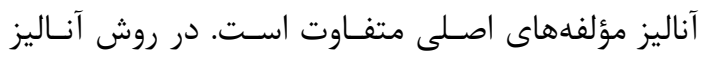

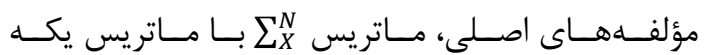

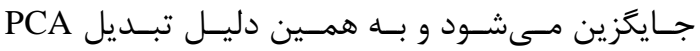

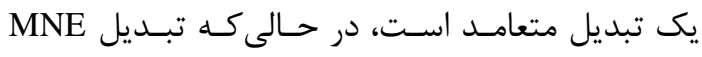
تبديلى غيرمتعامد خواهد بود. $a_{l}^{T} \sum_{X}^{N} a_{k}=$ • $l=k+\quad 1, r, \ldots, d$,

$k=1, r, \ldots, d-1$

بdعبارتى ديكر، مى توان ماتريس بردارهاى ويزرهى

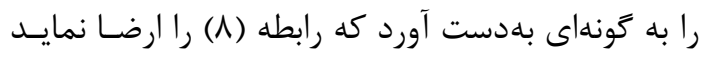
:[1 [1 ]

$$
A \sum_{X}^{S} A^{T}=\Lambda, \quad A \sum_{X}^{N} A^{T}=I \quad \text { رابطه (1) }
$$

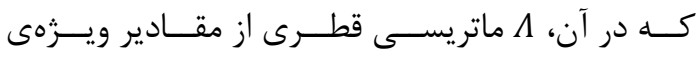
غيــر منفـى اسـت ( ماتريس يكه است. سطر k از ماتريس A برابـر اسـت بـا ماتئس

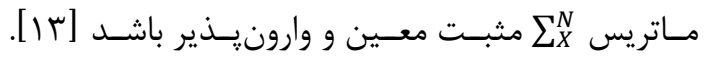

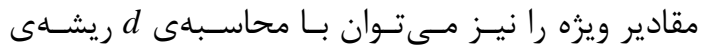
جند جملهاى رابطه (9) بلهدست آورد: $\left|\left(\sum_{X}^{N}\right)^{-1} \sum_{X}^{S}-\lambda I\right|=\cdot$

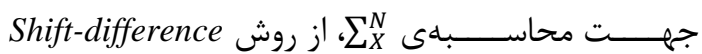

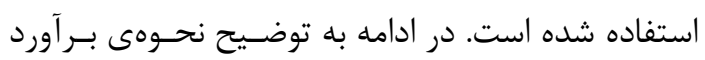




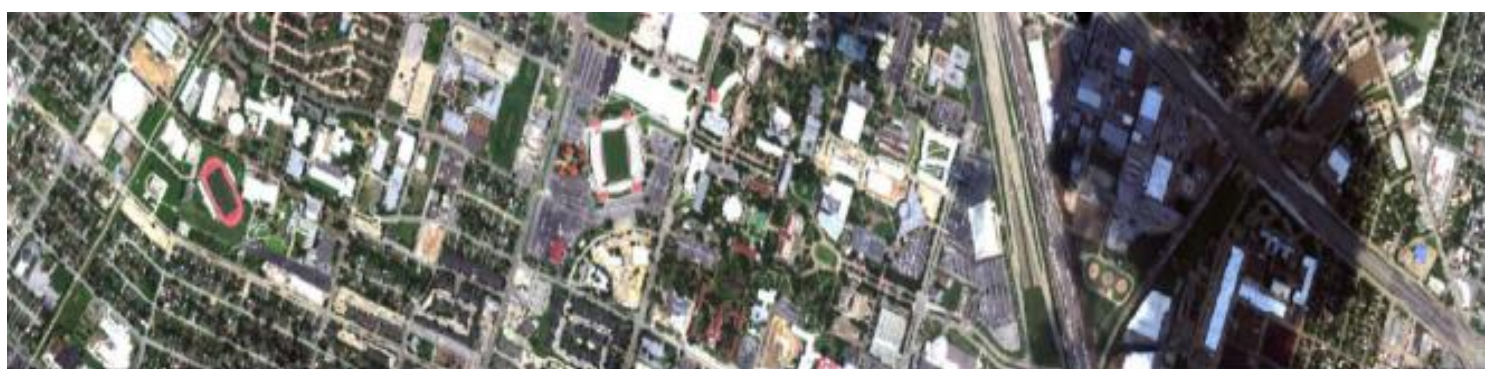

شكل ا: منطقه مورد مطالعه

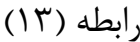

$\tilde{L}(\alpha)=\sum_{i=1}^{n} \alpha_{i}-\frac{1}{r} \sum_{i=1}^{n} \sum_{j=1}^{n} \alpha_{i} \alpha_{j} y_{i} y_{j} k\left(x_{i}, x_{j}\right)$ كه در آن، (k)

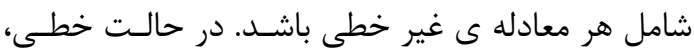

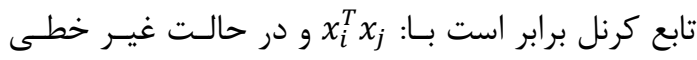

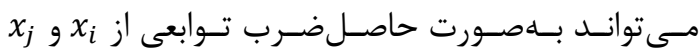
بيـان شـود:

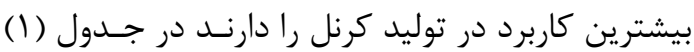
آورده شدهاند [1/1].

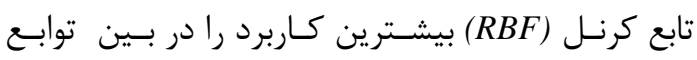

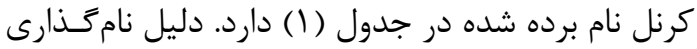

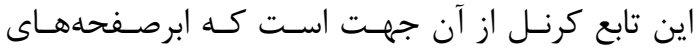

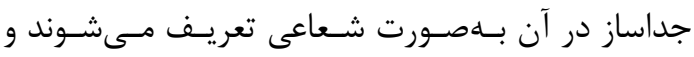

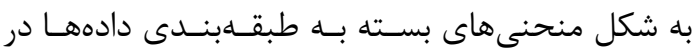

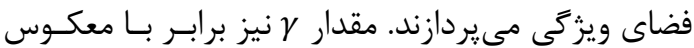

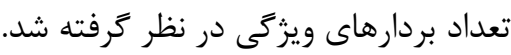

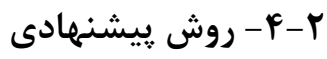

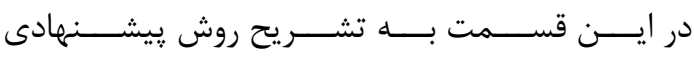

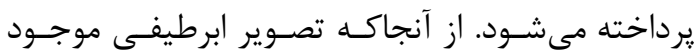

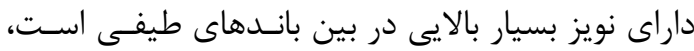

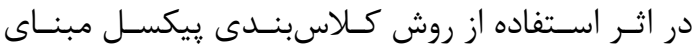

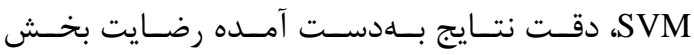
نخواهد بود. در نتيجه، بيش از استفاده از هر گونه روش

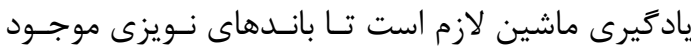
در تصوير ابرطيفى از بين باندهاى موجود حذف شـوند.

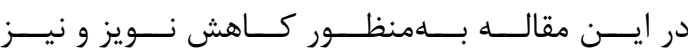

روش ماشينهاى بردار يشتيبان خطى سعى دارند تا بـاــا

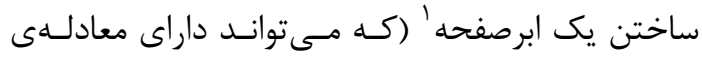

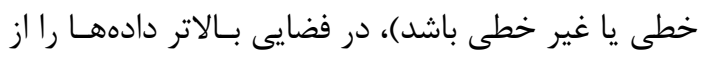

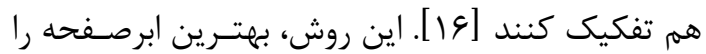

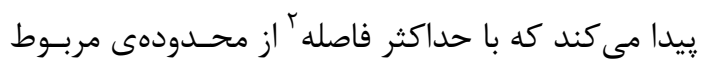

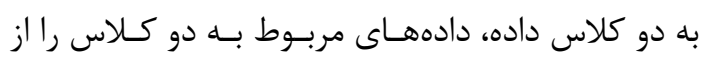
يكديخر تفكيك نمايد.

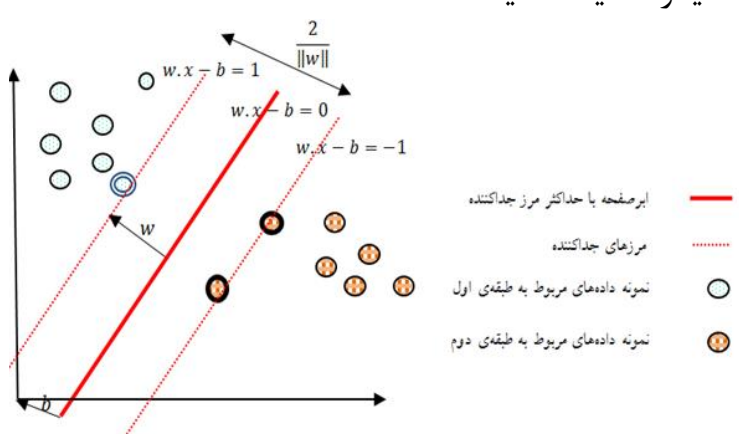

شكل r: ابرصفحه با حداكثر مرز جداساز به همراه مرزهاى جداساز براى طبقهبندى نمونه داده هاى مربوط به به دو كلاس

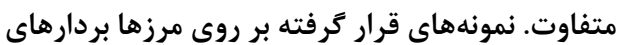

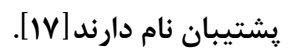

در حالت كلـى، رابطـهـ ( I ) كـهـ مربـوط بـه معادلـهى

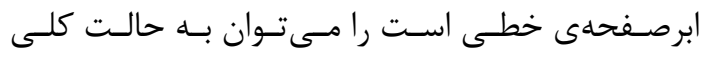

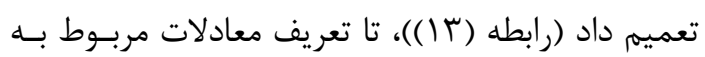
ابرصفحهى غير خطى را نيز شامل شود [1/1)] رابطه (T) $-\frac{1}{r} \sum_{i=1}^{n} \sum_{j=1}^{n} \alpha_{i} \alpha_{j} y_{i} y_{j} x_{i}^{T} x_{j}+\sum_{i=1}^{n} \alpha_{i}$

${ }^{1}$ Hyper-plane

${ }^{2}$ Maximum Margin 
بلهـورت پيكسـلى خواهنــد بـود. در نتيجـه، احتمـال

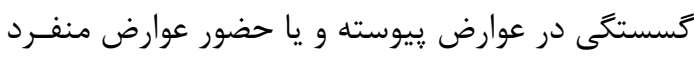
در نتايج بهدست آمده وجود خواهد داشـت. در نتيجـه،

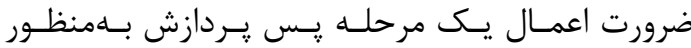

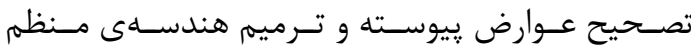
عوارضى كه بهدست انسان ساخته شدهاند، وجود خواهد داشت. بههمين دليل، يس از استخراج تمـامى عـوارض

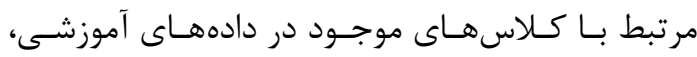

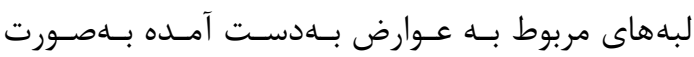

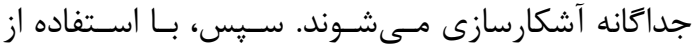
تبديل هاف بر روى تصوير مربـوط بـهـ لبـهـهـا امتـداد و

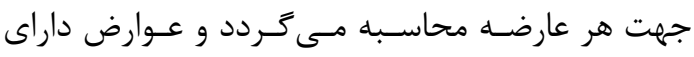

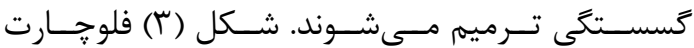
روش ييشنهادى را نشان مىدهد.
كاهش همبستخى بين بانـدهاى طيفـى، از روش MNF

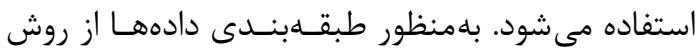

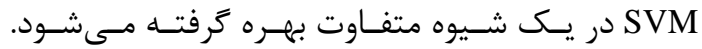

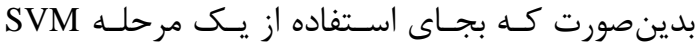

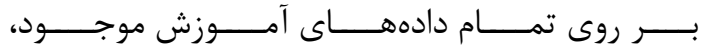
طبقابندى كننده SVM با معادله پايه شعاعى بـر روى

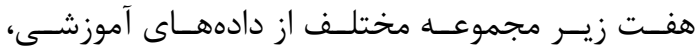

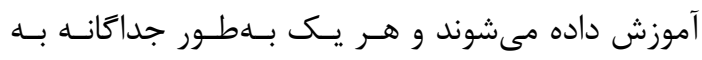
طبقلبندى عوارض موجود در تصاوير مىيردازند. سيس،

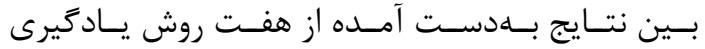
ماشينبردار رشتيبان راى گيرى انجام مىشود تا كـلاس نهايى مربوط به هر بيكسل مشخص شود. در اين مقالـه تابع كرنل مورد استفاده از نوع RBF مى مياشد. از آن جـا

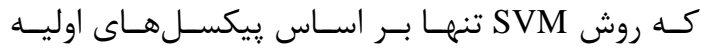

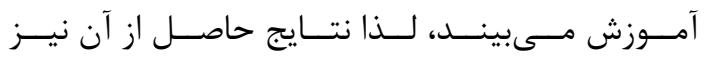
جدول ا: معادلهى مربوط به تابع كرنل برخى معادلات غير خطى معمول

\begin{tabular}{|c|c|}
\hline معادلهى مربوط به تابع كرنل & عنوان معادلهى غير خطى \\
\hline$k\left(x_{i}, x_{j}\right)=\left(x_{i} \cdot x_{j}\right)^{d}$ & معادلهى جند جملهاى همكن \\
\hline$k\left(x_{i}, x_{j}\right)=\left(x_{i} \cdot x_{j}+1\right)^{d}$ & معادلهى جند جملهاى ناهمكن \\
\hline$k\left(x_{i}, x_{j}\right)=\exp \left(-\gamma\left\|x_{i}-x_{j}\right\|^{r}\right), \gamma>$ & معادلهى تابع پِايه شعاعى (RBF) \\
\hline$k\left(x_{i}, x_{j}\right)=\tanh \left(\gamma x_{i} \cdot x_{j}+c\right), k>$ & معادلهى سيخموئيد (تانزانت هذلولى) \\
\hline
\end{tabular}
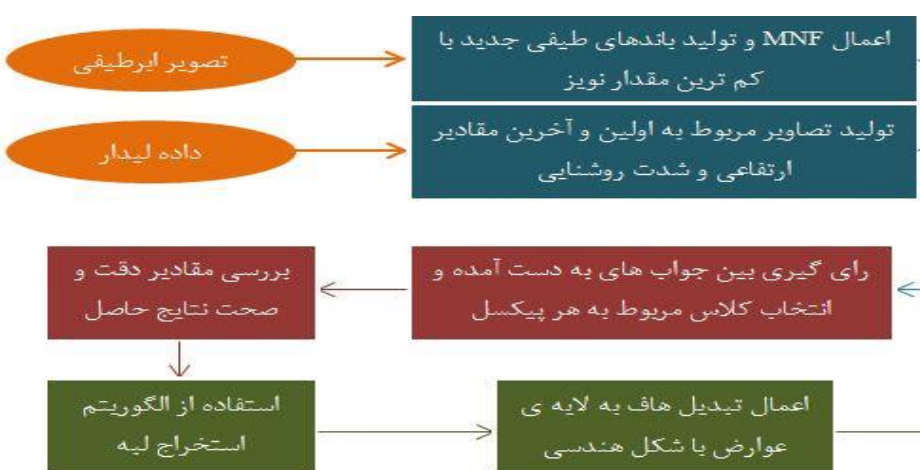

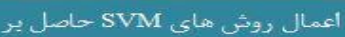

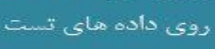

آموزث هفت روثى مخختلف SVM

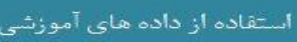

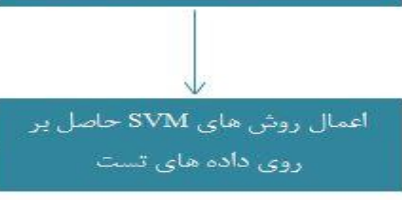

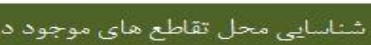

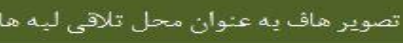

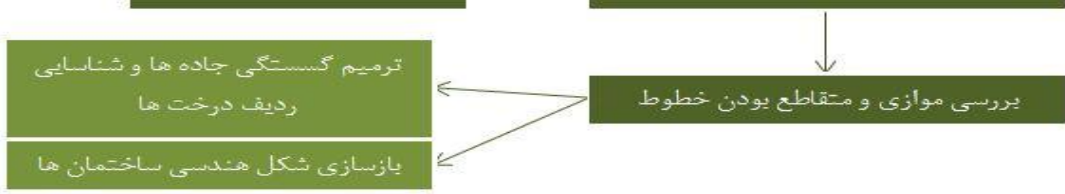

شكل r: فلوجارت روش پِيشنهادى ارائه شده در اين مقاله

${ }^{1}$ Radial Basis Function 


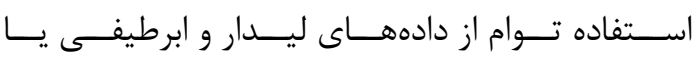

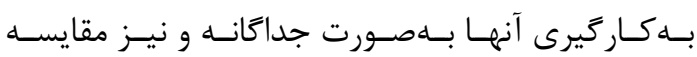

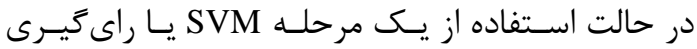
بين خروجىهاى هفت SVM مختلـف، نتـايج مربـوط به استخراج عوارض در جهار حالت مختلف به شرح زير بررسى شدند:

1 - اســتخراج عـــوارض از تصـــوير ابرطيفــى ازئ19

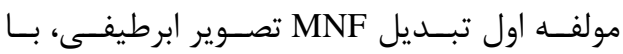

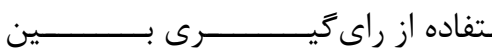

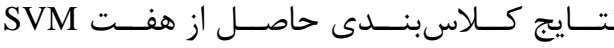

$$
\begin{aligned}
& \text { روش مختلف (شكل(ه- الف))، }
\end{aligned}
$$

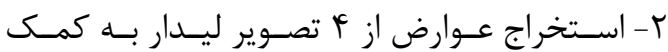

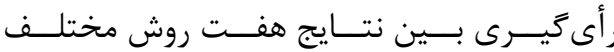

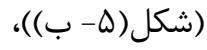

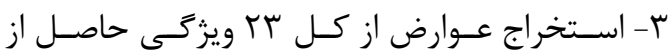
ادغام دادهى ابرطيفى و ليدار به كمك يك مرحله SVM

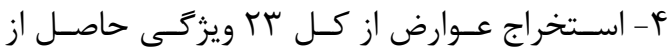

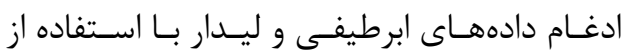
اعمال هفت روش مختلف (شكل(ه- د)).

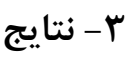

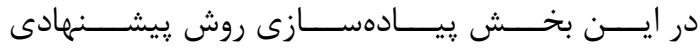

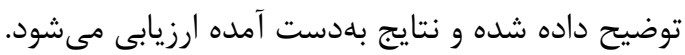
r-1-بيادهسازى روش بِيشنهادى ابتــدا دادهى ابرنقطــهى ليــدار موجــود، بــا اسـتفاده از

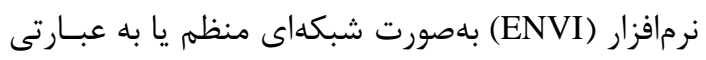
بهتر به تصـوير ليـدار تبـــيل شـدند. كـاهش بانـدهاى

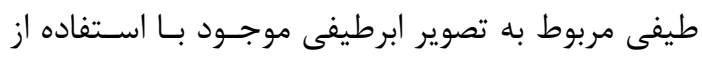

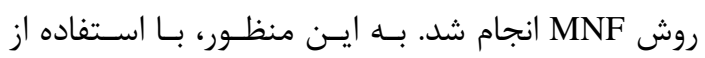

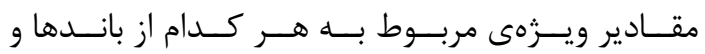

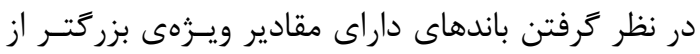

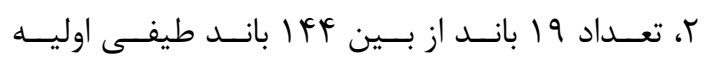

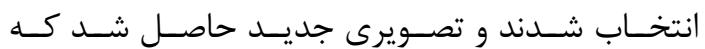

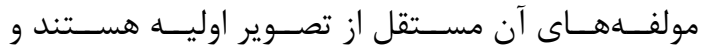

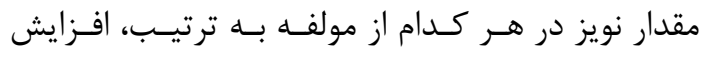

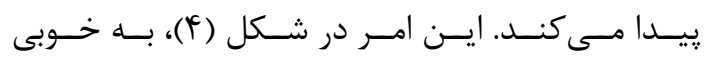
قابل مشاهده است. در ادامهى مراحل روش يُشيشنهادى، بــه جـاى اسـتفاده از تصــوير ابرطيفـى اوليـهـ از 19

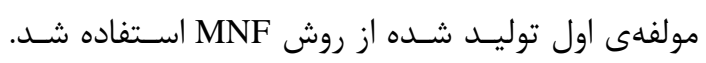

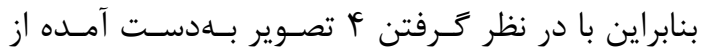

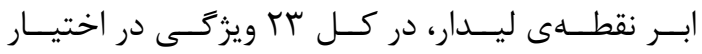

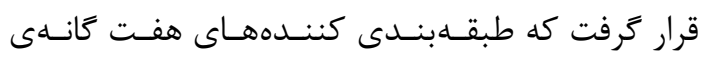

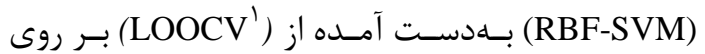
آنها اعمال خواهند شد.

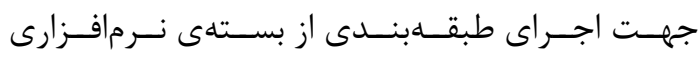

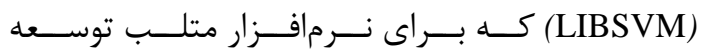

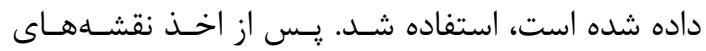

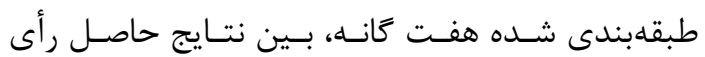

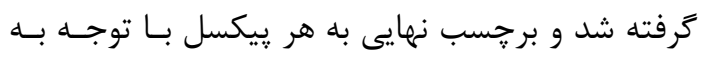

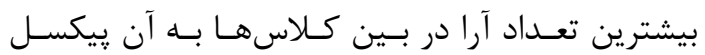

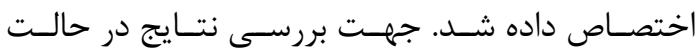

${ }^{1}$ Leave One Out Cross Validation 
جدول r. تعداد نمونه هاى آموزشى و نمونههاى آزمايشى كلاسهاى مختلف عوارض منطقه مورد مطالعه

\begin{tabular}{|c|c|c|c|}
\hline رنَ هر عارضه & تعداد ييكسل هاى & تعداد ييكسل هاى & 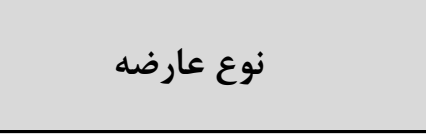 \\
\hline & $1 \cdot \Delta r$ & 191 & حَياه سالم \\
\hline & 1.94 & 19. & كياه خشك شده \\
\hline & $\Delta \cdot \Delta$ & 195 & تركيبـى از زياه سالم و خشك \\
\hline & $1 \cdot \Delta \varphi$ & $1 \wedge$ & درخت \\
\hline & $1 \cdot \Delta \varphi$ & 119 & خاى \\
\hline & IF & INT & آب \\
\hline & $1 \cdot V T$ & 199 & ساختمان مسكونى \\
\hline & $1 \cdot \Delta r$ & 191 & ساختمان تجارى \\
\hline & $1 \cdot 09$ & 191 & جاده \\
\hline & $1 \cdot r 4$ & 191 & بزرَراه \\
\hline & $1 \cdot \Delta \varphi$ & 111 & راه آهن \\
\hline & $1 \cdot 41$ & 195 & ياركينَ عمومى \\
\hline & rAD & $|1|^{c}$ & يار كينَ اختصاصى \\
\hline & TFV & 111 & زمين تنيس \\
\hline & FVT & $1 \wedge V$ & زمين دو و ميدانى \\
\hline
\end{tabular}

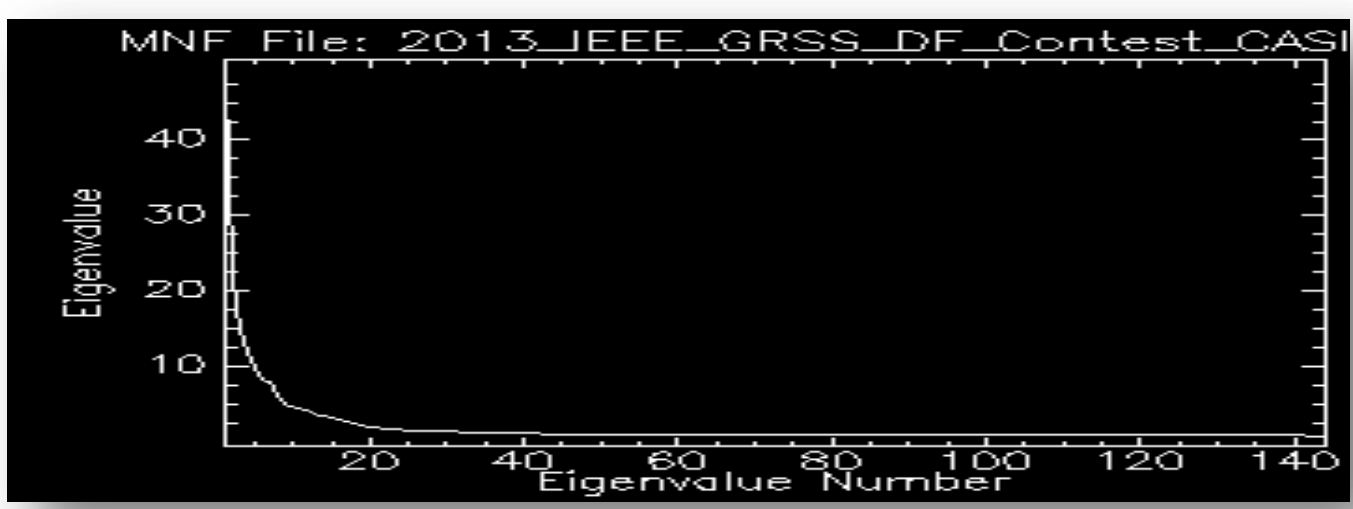

شكل f: مقادير ويزٔى باندهاى جديد بهدست آمده از تبديل MNF بر روى تصوير ابرطيفى اوليه با IFF باند طيفى 


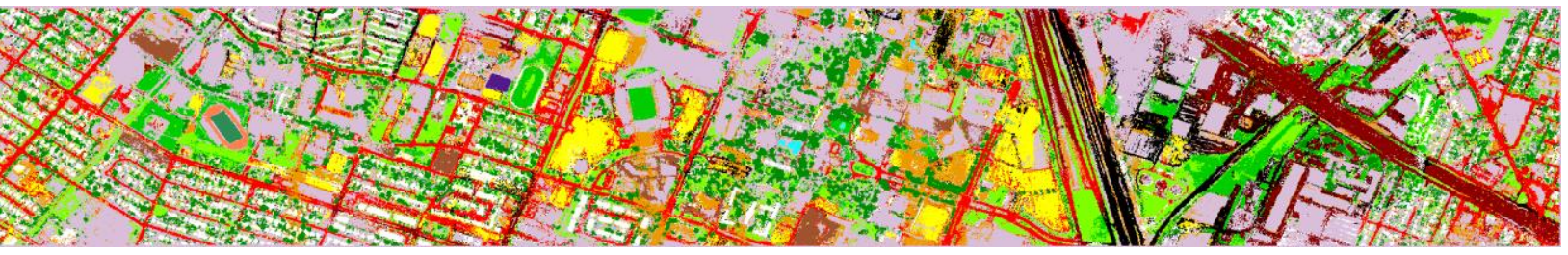

الف

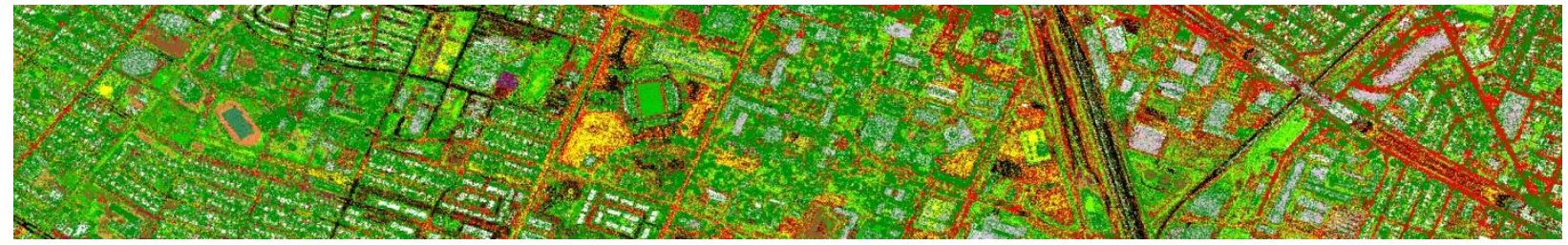

ب

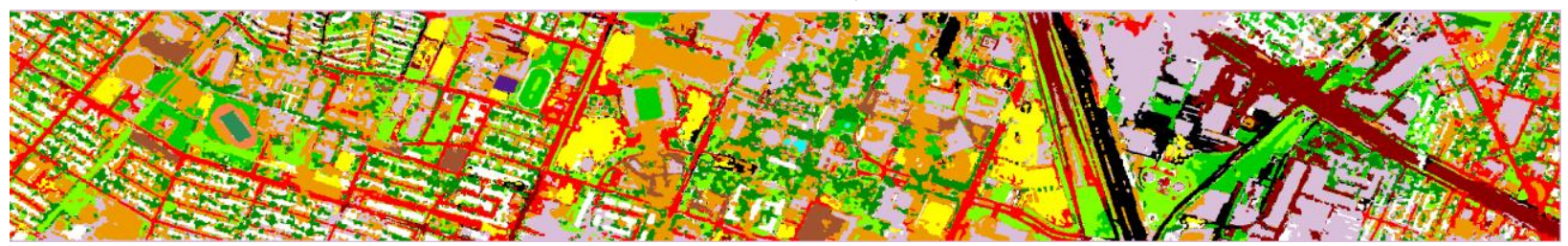

ج

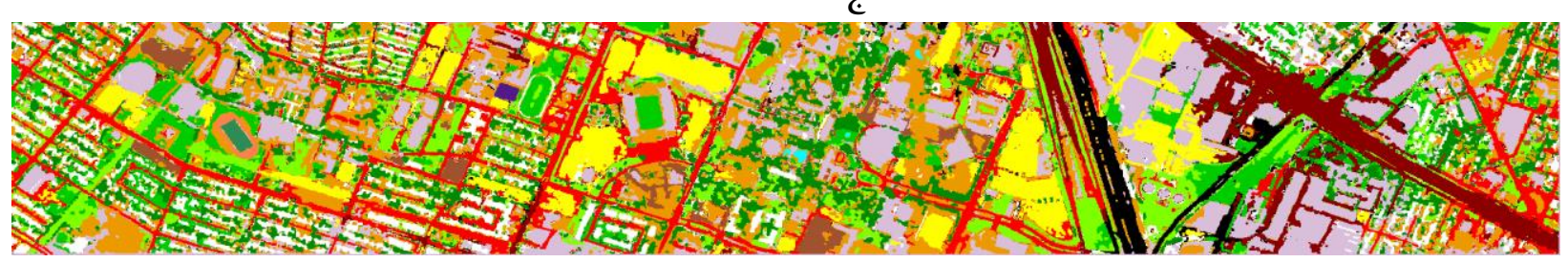

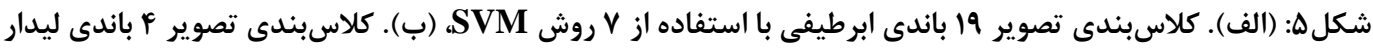

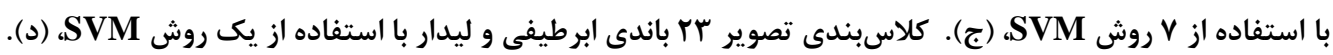

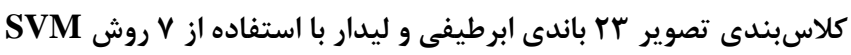

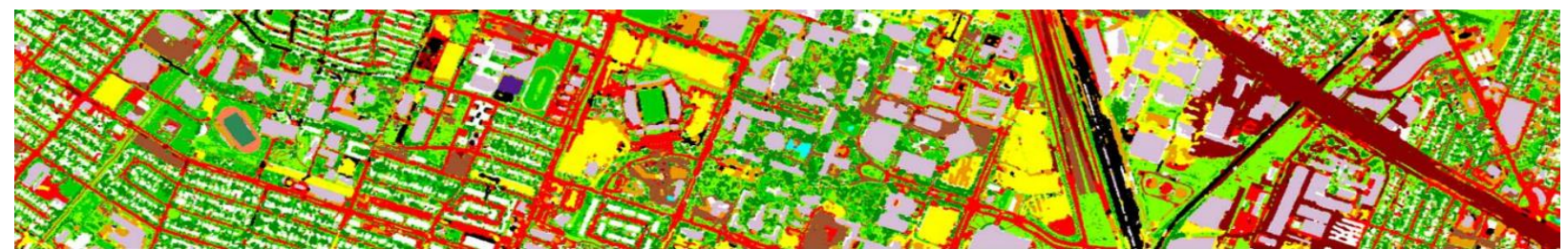

شكل 9 : نتيجهى كلاسبندى بلهدست آمده از روش بركزيده در مسابقهى بينالمللى ادغام دادهها

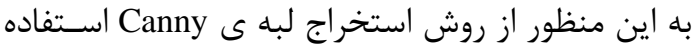

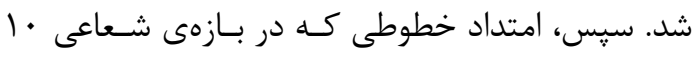

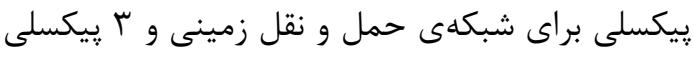

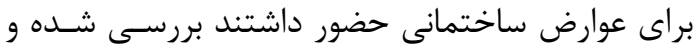

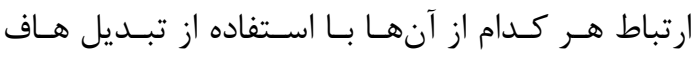

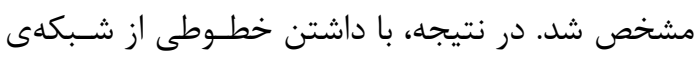

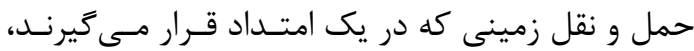

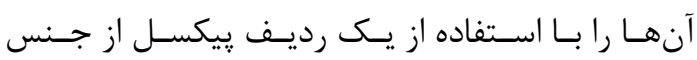

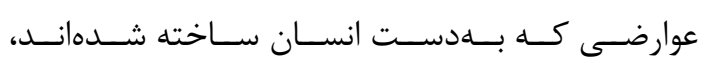

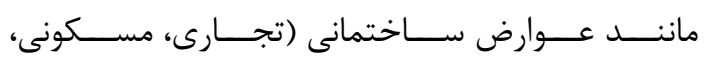

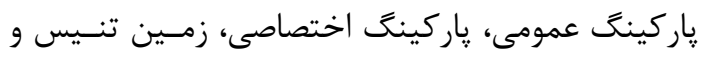

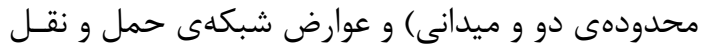

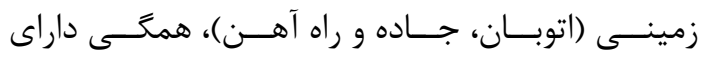

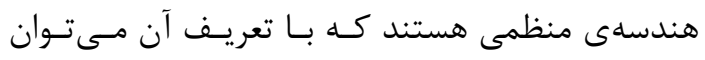

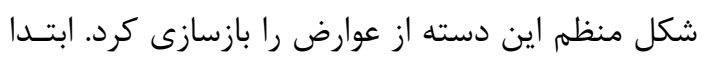

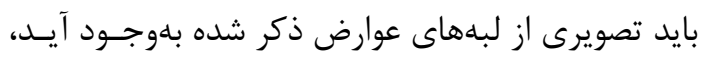


سه عارضهى درخت در يك امتداد قرار مى كرفتنــد، آن

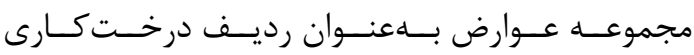
در نظـر كرفتـه مسى شـــند. در ضـمن، شـرط ديخــــ

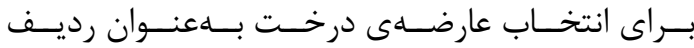

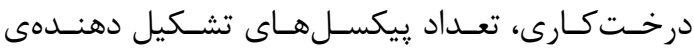

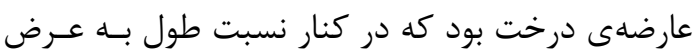

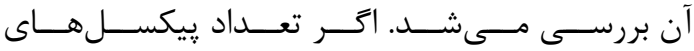

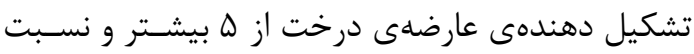

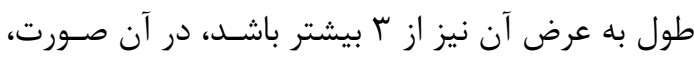

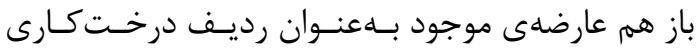

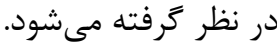

همان عارضه به يكديخر متصل كرده و به حالت بيوسته

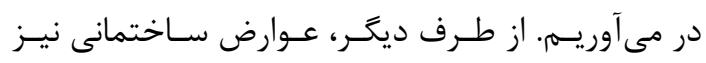
داراى شكل هندسى منظهم و مسـتطيل شـكل هسـتند. بههمين دليل، بهمنظور بازسازى شكل مـنظم هندسى

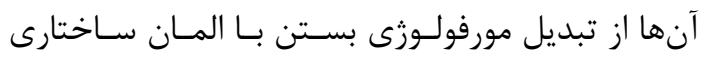

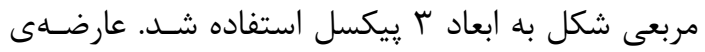
درخت را نيز مى توان به دو كلاس مجـزا تقسيمى كـرد:

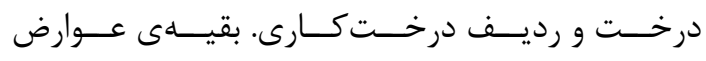
يوشش گياهى، عارضهى سطحى هستند. بهمنظور تعيين نقطهاى و خطى بودن عارضهى درخت،

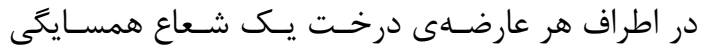

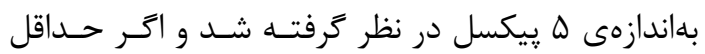

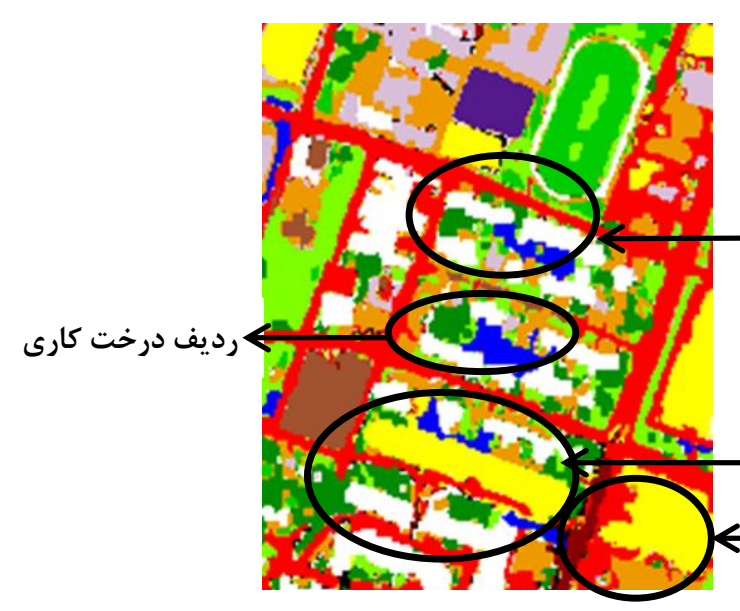

(ب)

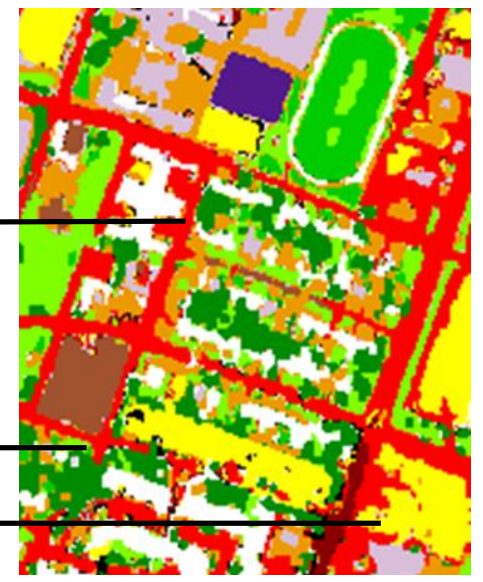

(الف)

شكل V (الف) كلاس بندى تصاوير موجود به روش ييشنهادى، (ب) ترميم عوارض استخراج شده با استفاده از تعريف شىء به به اسله

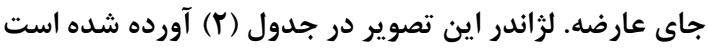

ها كلاس عارضهى مورد نظــر از بـين دادهــاى تسـت

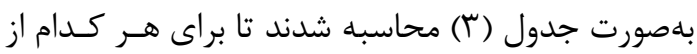

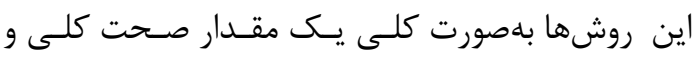

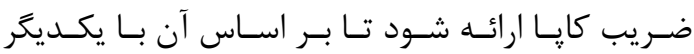
مقايسه شوند. r-r - ارزيابى دقت نتايج يس از محاسـبهى يارامترهـاى صـحت كلى و ضـريب كاياى مربوط به جهار روش نام برده شده براى هراس هر كدام

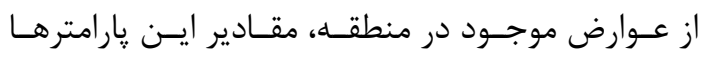
بلهورت كلى و به منظور شناسايى و استخراج همزمونان

جدول بّ: صحت كلى و ضريب كاياى روشهاى معرفى شده در استخراج تمامى عوارض موجود در منطقه

\begin{tabular}{|c|c|c|c|c|c|}
\hline 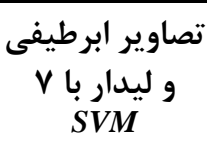 & تصاوير ابرطيفى ليدار بـ & $\begin{array}{c}\text { تصوير ليدار } \\
\text { SVM V V }\end{array}$ & $\begin{array}{c}\text { تصوير ابرطيفى VIM V } \\
\text { SVM }\end{array}$ & مسابقهى بين الملى بلى در & \\
\hline $99, \Delta T$ & $9 \cdot 199$ & $q \mu \cdot r$ & $91, \& 4$ & $q \cdot, r$. & صحت كلى (.) \\
\hline$\cdot, 901$ & - $V \Delta Q V$ & • & $\cdot / 199$ & $\cdot / 190$ & ضريب كايا \\
\hline
\end{tabular}




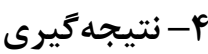

در اين تحقيق روشى جهت اسـتخراج عـوارض مختلـف شهرى از دادهاى ليدار و ابرطيفى ارائه شده اسـت كـهـ

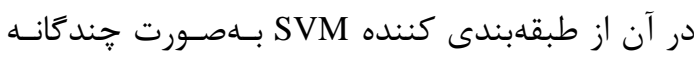
استفاده شده است. جهت بررسى مزاياى استفاده توام از

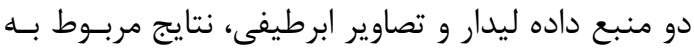

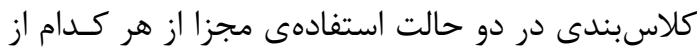
تصاوير ابرطيفى و ليدار نيز محاسبه شدند كه در نتيجه داندان مقادير صحت كلى و ضريب كايا براى اين دو حالت نيـز

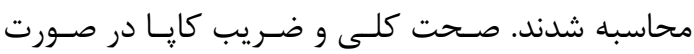

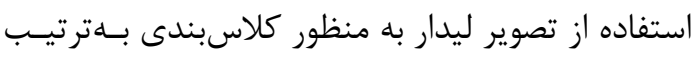

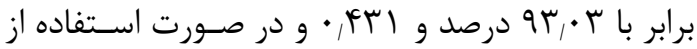
تصوير ابرطيفى بهمنظور كلاسبندى به ترتيب برابـر بـا

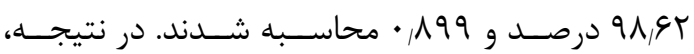
با افزايش ضريب كاياى مربـوط بـهـ تصـوير ابرطيفـى از 1991/ • به 901, • با افزودن دادهى ليدار، نشان دهندهى

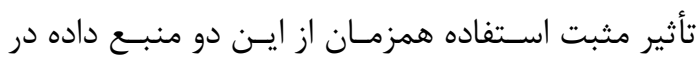

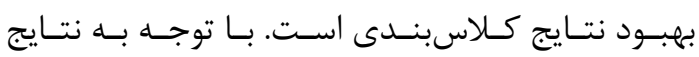

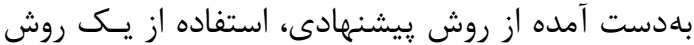

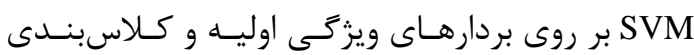

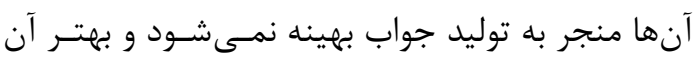

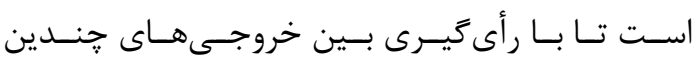

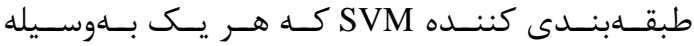

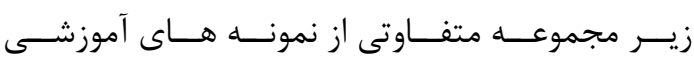
تعليم ديدهاند، كلاس نهايى هر يِيكسل مشـخص شـود.

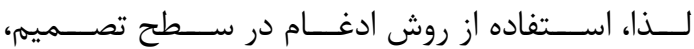

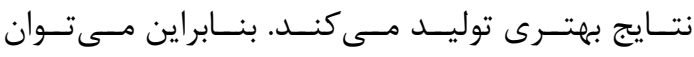

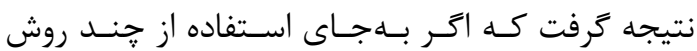
SVM از يك روش گروهى استفاده كنيه، با ثابتمانسدن

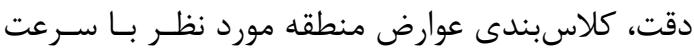

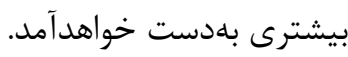

همانطور كه از نتايج جدول (r) مشخص اسـت، مقـادير صحت كلى و ضريب كايا در روش استفاده هـــمزمـان از

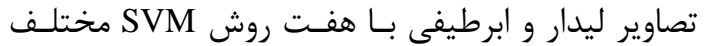
بهمنظور استخراج عوارض، بيشتر از دو حالتى است كـهـ

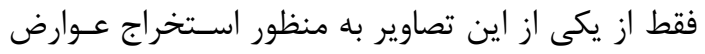

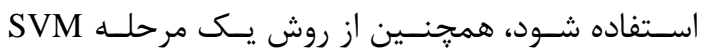

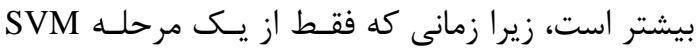

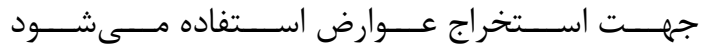
خطاى طبقهبندى تصادفى افزايش مى ابيـــ و در نتيجـهـ

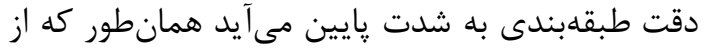

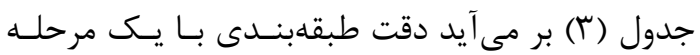

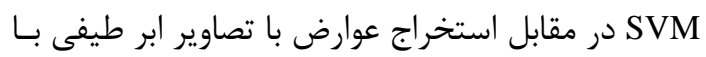
هفت روش SVM مختلف كمتــ اسـت در صـورتى كـهـ روش يك مرحله SVM شامل اطلاعات ارتفــاعى ليـدار

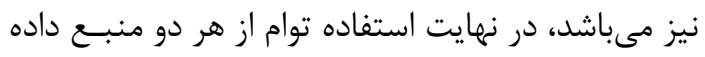
و طبقهبندى آنها با קندين روش SVM مختلف باعث بهبود نتايج مربوط به كلاسبندى شده است. همجنـين

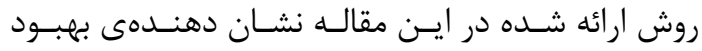

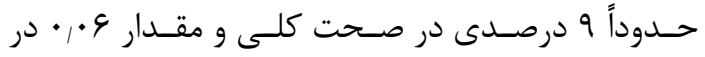

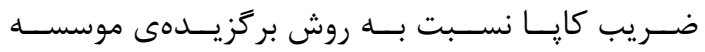

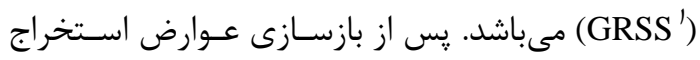

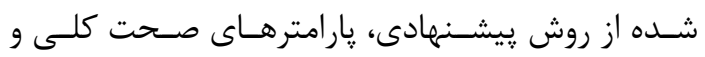
ضريب كايا بار ديكر براى دادههاى تسـت محاسـبه و بـا بـا

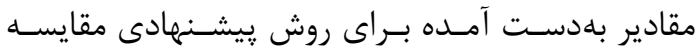

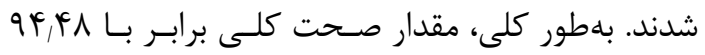

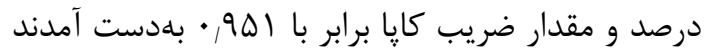

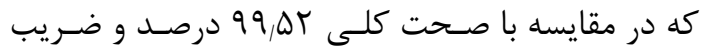

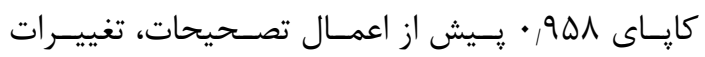
زيادى نداشتهاند. در نتيجه، اشياء استخراج شده يس إس از

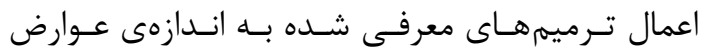
استخراج شده از روش پِيشنهادى قابل قبول هسـتند و و

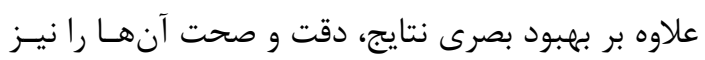

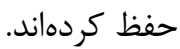

${ }^{1}$ Geoscience \& Remote Sensing Society 
[1] P. Pahlevani, H, Amini Amir Kalaei, and S. Sadeghian, "Extracting Land Digital Model from Lidar Data and Aerial Images and Identifying Urban Buildings and Passages by Present Nerve Network", Journal of Soft Computing and Information Technology",Vol. 2, No. 4, 1394.

[2] S. Sadeghian, A. Aieneh, "Extraction of Vegetation Cover in Urban Areas by Means of Merging of Lidar and Superiority Data", Presented at 22nd Geomatics National Conference, Tehran, Iran, 1394.

[3] A. Benedikttson. and I. Kanellopoulos, "Classification of Multisource and Hyperspectral Data based on Decision Fusion", IEEE Transactions on Geoscience and Remote Sensing, Vol. 37, No. 3, pp. 1367-1377, 1999.

[4] M. Turker, and D. Koc-San, "Building Extraction from High-Resolution Optical Space-borne Images using the Integration of Support Vector Machine (SVM) Classification", Hough Transformation and Perceptual Grouping, International Journal of Applied Earth Observation and Geoinformation, Vol. 34, pp. 58-69, 2015.

[5] A, Matkan, M. Hejeb, and S, Sadeghian, "Road Extraction from Lidar Data using Support Vector Machine Classification, Phogrammetric Engineering and Remote Sensing (PE\&RS) Journal, Vol. 80, No. 5, pp. 409-422, May 2014.

[6] Z. Azizi, and S. Sadeghian, "Forest Canopy Modeling with LIDAR Data and Digital Aerial Imagery, 2nd International Conference on Sensors and Models in Photogrammetry and Remote Sensing (SMPR'13, Tehran, Iran, 2013.

[7] B. Bigdeli, F. Samadzadegan, and P. Reinartz, "A decision Fusion Method Based on Multiple Support Vector Machine System for Fusion of Hyperspectral and LiDAR Data", International Journal of Image and Data Fusion, Vol. 5, No. 3, pp. 196-20, 2014.

\section{مراجع}

[8] C.W, Geerling, M. L. abrador-Garcia, J.G.P.W. Clevers, A.M.J. Ragas, and A.J.M. Smits, "Classification of Floodplain Vegetation by Data fusion of Spectral (CASI) and LIDAR Data", International Journal of Remote Sensing, Vol. 28, pp. 4263-4284, 2007.

[9] M. Voss, and R. Sugumaran, "Seasonal Effect on Tree Species Classification in an Urban Environment using Hyper-spectral Data, LIDAR and an Object-oriented Approach Sensors", Vol. 8, pp. 3020-3036, 2008.

[10] G.W. Geerling,, M.J. Vreeken-Buus, P. Jesse, A.M.J. Ragas, and A.J.M. Smits. "Mapping River Floodplain Ecotopes by Segmentation of Spectral (CASI) and Structural (LIDAR)" Remote Sensing Data, River Research and Applications, Vol. 25, No. 7, pp. 795-813, 2009.

[11]J.W. Boardman, and F.A. Kruse, "Automated Spectral Analysis: A geological Example using AVIRIS Data, Northern Grapevine Mountains, Nevada: in Proceedings", 10th Thematic Conference, Geologic Remote Sensing, Vol. 9, No. 12, May 1994, San Antonio, Texas, Chapter I, pp. 407-418, 1994.

[12] A.A. Green, M. Berman, P. Switzer, and M.D. Craig, "A Transformation for Ordering Multispectral Data in Terms of Image Quality with Implications for Noise Removal", IEEE Transactions on Geoscience and Remote Sensing, Vol. 26, No. 1, pp. 65-74, 1988.

[13]F. Graybill, Matrices with applications in statistics, 2nd Edition, Wadsworth, Belmont, California. 1983.

[14] V. Vapnik, and A. LERNER, "Pattern Recognition using Generalized Portrait Method", Automation and Remote Control, Vol. 24, pp. 774-780, 1963.

[15] T. Joachims, "Making large-scale SVM learning practical”, in B. Sch"olkopf, C.J.C 
. Burges, and A.J. Smola, Editors, Advances in Kernel Methods - Support Vector Learning, Cambridge, MA, MIT Press, 1998.

[16] V. Vapnik, Statistical Learning Theory, Wiley, New York, 1998.

[17]B.E Boser, I. Guyon, V. Vapnik, “A Training Algorithm for Optimal Margin
Classifiers", Proceedings of the Fifth Annual Workshop on Computational Learning Theory, ACM Press, pp. 144-152, 1992.

[18] C. Cortes, V. Vapnik, "Support Vector Network. Machine Learning”, Vol. 20, pp. 273-297, 1995. 


\title{
Urban Features Production with Combining LiDAR and Hyperspectral Data
}

\author{
Seyed Yousef Sajjadi ${ }^{1 *}$, Omid Aieneh ${ }^{2}$
}

1- Assistant Prof., Dep. Of Surveying Engineering, Tafresh University, Tafresh Iran

2- Msc Student, Dep. Of Surveying Engineering, Tafresh University, Tafresh Iran

\begin{abstract}
The main problems of hyper spectral data are large number of bands, high dependency between them and different signal to noise ratio in each band. To reduce dimensions of the feature space, minimizing noise and spectral dependence between bands, the MNF method has been applied to achieve better results in this paper. By applying this algorithm, the 144 bands of hyper spectral data were reduced to 19 suitable bands. Then from LiDAR data, the image height and intensity of the return signal received from the first and the last pulse of the laser were examined by LiDAR sensor. At last, the 19 spectral bands extracted from hyper spectral data have been fusion with 4 images of LiDAR data at the pixel level to create 23 suitable spectral bands. In order to detect and extract any study feature of the area on 23 spectral bands, seven different SVM methods were applied and finally by majority voting in the decision-making level between 7 obtained results, the class of each pixel was turned out. Morphology closing transform for repairing buildings and Hough transform for reconstructing the network effects of the fragmentation of land transportation were used on the results of pixels basis SVM method to regulate man-made side structure as well as the individual pixels which reduced. The results in this paper indicates the $99.52 \%$ overall accuracy and .958 kappa efficiency which compared to the GRSS chosen institution method. 0.6 Kappa coefficient has been improved. Used data are air-borne LiDAR and hyper spectral scenes requested and downloaded from the organized of a recent contest in data fusion domain.
\end{abstract}

Key words: Hyper Spectral, LiDAR, Morphology, Support Vector Machine, Fusion.

Correspondence Address : Photogrammetric Group, Department of Geomatics, School of Civil Engineering,

University of Tafresh, Tafresh, Iran

Tel : +98 8636227659

Email: sajjadi@tafreshu.ac.ir 